\title{
A new species of Perinereis (Polychaeta, Nereididae) from Florida, USA, with a key to all Perinereis from the American continent
}

\author{
Jesús Angel de León-González ${ }^{1, \dagger}$, Carrie A. Goethel ${ }^{2, \ddagger}$ \\ I Universidad Autónoma de Nuevo León, Facultad de Ciencias Biológicas, Ap. Postal 5, Suc. "F", San Nicolás \\ de los Garza, Nuevo León, 66451, México 2 Ecological Associates, Inc. P. O. Box 405. Jensen Beach, Florida \\ 34958, USA \\ † urn:lsid:zoobank.org:author:F347D71F-DDEA-4105-953F-4FE71A5D6809 \\ $\ddagger$ urn:lsid:zoobank.org:author:91B7298E-5C4E-4AE4-993C-3332B4F9258A \\ Corresponding author: Jesús Angel de León-González (jesus.deleongn@uanl.edu.mx) \\ Academic editor: Chris Glasby | Received 19 December 2012 | Accepted 11 June 2013 | Published 24 June 2013 \\ urn:lsid:zoobank.org:pub:A0223BCA-OB80-4FF2-96B5-714C1E154C89 \\ Citation: de Leon J, Goethel CA (2013) A new species of Perinereis (Polychaeta, Nereididae) from Florida, USA, with a \\ key to all Perinereis from the American continent. ZooKeys 312: 1-11. doi: 10.3897/zookeys.312.4535
}

\begin{abstract}
Specimens belonging to a new species of Perinereis Kinberg, 1865 were collected from natural oyster reefs in an estuarine environment on Florida's southwest coast. The genus Perinereis includes more than 70 species, of which, P. aibuhitensis (Grube, 1878), P. brevicirrata (Treadwell, 1920), P. camiguinoides (Augener, 1922), P. jascooki Gibbs, 1972, P. kuwaitensis Mohammad, 1970, P. singaporiensis (Grube, 1878), P. vancaurica (Ehlers, 1868) and the new species have two short bars on Area VI and notopodial dorsal ligules that are not greatly expanded. The most geographically close species is $P$. brevicirrata. The new species can be distinguished from $P$. brevicirrata by the absence of a notopodial prechaetal lobe, Area $\mathrm{V}$ with 3 cones in a triangle, and Area VII-VIII with two well-defined rows of 33 paragnaths, the basal row having longer paragnaths in relation to the distal ones. The new species resembles $P$. singaporiensis based on the absence of notopodial prechaetal lobe; however, the two species differ in some morphological characteristics such as tentacular cirri length, shape of dorsal notopodial ligules, and falciger blades. A key to all American species of Perinereis is included.
\end{abstract}

\section{Keywords}

Annelida, polychaetes, Nereididae, new species, taxonomy, Florida, Western Atlantic

Copyright J.A. de León-González, C.A. Goethel. This is an open access article distributed under the terms of the Creative Commons Attribution License 3.0 (CC-BY), which permits unrestricted use, distribution, and reproduction in any medium, provided the original author and source are credited. 


\section{Introduction}

Nereididae Blainville, 1818 is probably the most well known family of Polychaeta, with 44 genera and 677 species (Read and Fauchald 2012), although the number of species could be over estimated. The importance of this family is manifested by its high diversity and abundance in practically all marine benthic environments, from the supralittoral to the abyssal depth. One of the most diverse genera in the family is Perinereis, established by Kinberg (1865). Perinereis is characterized principally by the ornamentation of pharyngeal paragnaths in Area VI, which may be simple (short or long ribbon-shaped) or fragmented transverse bars. It is a genus consisting globally of around 74 species (Read and Fauchald 2012). Bakken and Wilson (2005) found that Perinereis may be polyphyletic. Twenty-two species are currently known from the Americas, and of those, seven have been reported from Eastern Tropical America: P. anderssoni Kinberg, 1865 described from Brazil; P. cariacoensis Lińero-Arana, 1983 and P. mochimaensis Liñero-Arana, 1983 from Venezuela; P. cariboea de León-González $\&$ olís-Weiss, 1998 from Mexican Caribbean, P. floridana Ehlers, 1868 from Florida, USA, P. ponteni Kinberg, 1865 from Brazil, and P. vancaurica Ehlers, 1868 from Thailand. The latter is reported for the region by many authors, including Fauvel (1919) from French Guiana, Wesenberg-Lund (1958) from Bonaire, Lana (1984) from Pontal do Sul and Pecas Island, Brazil, and Santos and Lana (2000) from Brazil.

In the present work, a new species of Perinereis from the west coast of Florida is described for the first time. Further, records of Indo-Pacific nereidids reported from the Americas, such as $P$. vancaurica, are evaluated.

\section{Material and methods}

The material analyzed for this study was collected in December 2010 by Florida Atlantic University, Department of Biological Sciences/Harbor Branch Oceanographic Institute from natural oyster reefs within Rookery Bay National Estuarine Research Reserve near Naples, Florida. Sampling in Rookery Bay took place as part of the BP Oil Spill Oyster Study, an impact study on the effects of an oil spill on the oyster reef systems in Florida, funded by the Florida Institute of Oceanography. Samples were hand collected at low tide using a $0.12 \mathrm{~m}^{2}$ collection quad to a depth of $7.6 \mathrm{~cm}$. The materials were screened through a $2.0 \mathrm{~mm}$ mesh sieve. The collection team, led by Dr Donna Devlin, included Dr Holly Nance, Dr Loren Coen, Pedro Lara, and Dana Smith. Specimens were fixed with formalin and preserved in 70\% isopropyl alcohol, no stain was used. Material was deposited in the Los Angeles County Museum, Allan Hancock Foundation (LACM-AHF), the Zoologische Museum, Hamburg, Germany (HZM), the Polychaetological Collection of the Universidad Autónoma de Nuevo León (UANL), and the Florida Fish and Wildlife Conservation Commission - Fish and Wildlife Institute Invertebrate Collection, St. Petersburg, Florida (FSBC I). A key to all known American species of Perinereis is included. 


\section{Results}

\section{Systematics}

Class Polychaeta Grube, 1850

Order Phyllodocida Örsted, 1843

Family Nereididae Blainville, 1818

Genus Perinereis Kinberg, 1865

\section{Perinereis rookeri sp. $\mathrm{n}$.}

urn:lsid:zoobank.org:act:6177521A-A7AF-43E7-9C82-57A39E408436

http://species-id.net/wiki/Perinereis_rookeri

Figures 1, 2

Type material. West coast of Florida, Naples, Rookery Bay, December 17-22, 2010 (holotype, UANL 7841), and 3 paratypes (HZM P-27422), FLW-Site3-Reef5-Rep2, $26^{\circ} 00.56^{\prime} \mathrm{N}, 81^{\circ} 44.90^{\prime} \mathrm{W}, 22 / 12 / 2010$; One Paratype (LACM-AHF-4998), FLWSite1-Reef2-Rep1, $26^{\circ} 01.55^{\prime} \mathrm{N}, 81^{\circ} 44.00^{\prime} \mathrm{W}, 17 / 12 / 2010$; One Paratype (UANL

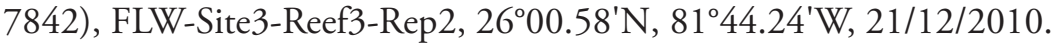

Additional material. West Coast of Florida, Naples, Rookery Bay, December 17-21, 2010. One specimen (FSBC I 106475) from FLW-Site1-Reef3-Rep2, $26^{\circ} 01.54^{\prime} \mathrm{N}, 81^{\circ} 44.23^{\prime} \mathrm{W}, 17 / 12 / 2010$; and one specimen from FLW-Site3-Reef3Rep2, 26을.

Description. Holotype complete, 84 chaetigers, $52 \mathrm{~mm}$ in length, $2.5 \mathrm{~mm}$ wide at chaetiger 10 (excluding parapodia); $3.72 \mathrm{~mm}$ wide at chaetiger 10 (including parapodia). Paratypes complete with 75-87 chaetigers, $42-65 \mathrm{~mm}$ long, and 0.8-2.7 mm wide at chaetiger 10 (excluding parapodia).

Prostomium slightly wider than long, antennae minute, about $1 / 3$ length of prostomium. Two pairs of eyes of similar size in trapezoidal arrangement. Biarticulate palps globose, with four pairs of tentacular cirri, posterodorsal pair extending back to posterior margin of first chaetiger (Fig. $1 \mathrm{~A}$ ).

Paragnaths black, cones on maxillary ring, cones and bars on oral ring, those of maxillary ring smaller. Area $\mathrm{I}=2$ cones in a line; Area $\mathrm{II}=13$ cones in 3 irregular rows; Area III $=18$ cones in a quadrangular arrangement of 3 irregular rows, flanked by a left line of 3 cones and a right line of 5 cones; Area IV= 20 cones on the left, 17 cones on the right in a triangular patch, without bars; Area $\mathrm{V}=3$ cones in a triangle; Area VI= two short transverse bars; Area VII-VIII= 33 cones in two rows, basal row with slightly longer paragnaths in relation to those of the distal row (Fig. 1 A-B, 2 A-B).

First two parapodia uniramous, all others biramous. Parapodia of anterior region with short dorsal cirri, not longer than dorsal ligule, inserted basally, dorsal ligule subulate, notopodial ventral ligule subtriangular, without notopodial prechaetal lobe; neuropodia with superior lobe rounded, inferior lobe reduced, postchaetal lobe rounded, ventral ligule subulate, ventral cirri minute, inserted basally (Fig. 1 C). Parapodia of median and posterior region similar in shape, notopodia with short dorsal cirri inserted 

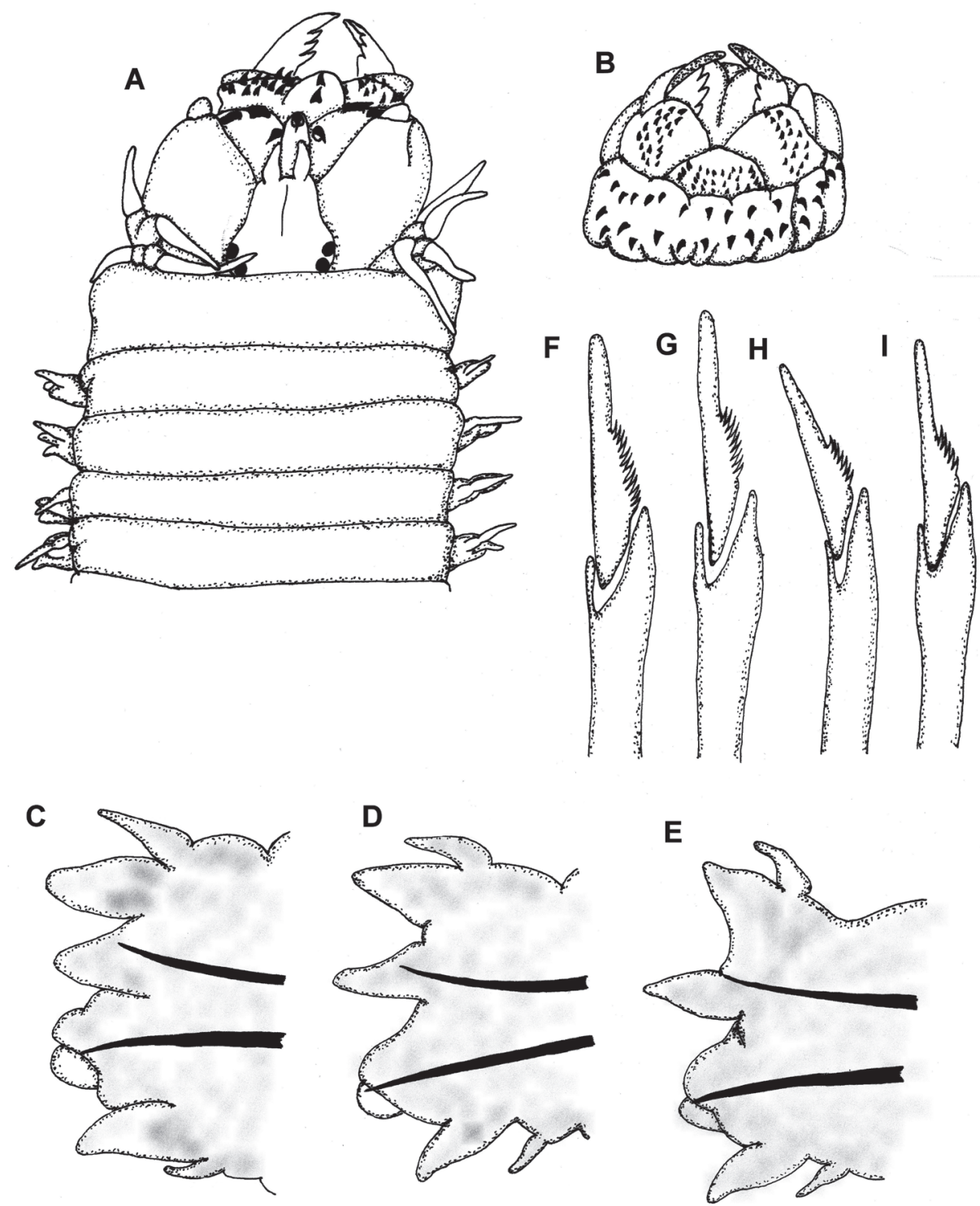

Figure I. Perinereis rookeri sp. n. A Anterior end, dorsal view B Proboscis, ventral view C-E Parapodia of chaetigers 11, 30 and 61, anterior view $\mathbf{F}$ Supracicular neuropodial heterogomph falciger, chaetiger 11 G Infracicular neuropodial heterogomph falciger, chaetiger $11 \mathbf{H}$ Supracicular neuropodial heterogomph falciger, chaetiger 61 I Infracicular neuropodial heterogomph falciger, chaetiger 61. Measures: $\mathbf{A}-\mathbf{B}=1 \mathrm{~mm} ; \mathbf{C}-\mathbf{E}=250 \mu ; \mathbf{F}-\mathbf{I}=30 \mu$.

medially, dorsal ligule subtriangular, notopodial ventral ligule subulate (Fig. 1 D-E); neuropodial structures similar in shape along body.

Chaetation similar throughout body. Notochaetae all homogomph spinigers. Supracicular neurochaetae consisting of homogomph spinigers and heterogomph fal- 
cigers, the latter with straight blades denticulate on the basal half (Fig. 1 F-G). Falciger blades of anterior and median parapodia longer than those of posterior ones. Infracicular neurochaetae consisting of heterogomph spinigers and heterogomph falcigers, the latter similar in shape and size gradation of dentition to supracicular ones (Fig. $1 \mathrm{H}-\mathrm{I}$ ). Anterior and median spinigers slightly longer than posterior ones.

Pygidium with terminal anus and a pair of short cirri $(1.2 \mathrm{~mm}$ long) inserted ventrally to anal opening.

Remarks. Type and non-type specimens exhibit variation in paragnath counts for Area I, as follows. A single specimen with 1 paragnath, two specimens with 3 in a triangle, and the rest with 2 paragnaths in a line.

Discussion. Hutchings et al. (1991) created an informal grouping of species belong to Perinereis based on the ornamentation of pharyngeal Area VI, and the development of the dorsal ligule. The species described here belongs to group $2 \mathrm{~A}$ based on the presence of two short bars on Area VI and a dorsal ligule that is not greatly expanded. The following species belong to this group: P. aibuhitensis (Grube, 1878) from the Philippines, P. brevicirrata (Treadwell, 1920) from Southern Brazil, P. camiguinoides (Augener, 1922) from Juan Fernandez Island, P. jascooki Gibbs, 1972 from the Cook Islands, P. kuwaitensis Mohammad, 1970 from Kuwait, P. singaporiensis (Grube, 1878) from Singapore, and $P$. vancaurica (Ehlers, 1868) from Nicobar Islands.

This group can be further subdivided by the presence or size of the notopodial prechaetal lobe. Perinereis aibuhitensis, $P$. jascooki, P. kuwaitensis, and P. singaporiensis, possess only dorsal and median ligules, and the notopodial prechaetal lobe is reduced or absent. The absence of a notopodial prechaetal lobe places Perinereis rookeri sp. $\mathrm{n}$. within this subgroup. Perinereis rookeri $\mathrm{sp}$. $\mathrm{n}$. and P. singaporiensis are the most similar; both species have Area III with a rectangular group of small paragnaths arranged in 4 irregular rows, flanked by 8 cones in two vertical lines. The two species differ by the length of the tentacular cirri, the shape of the dorsal ligule, and the dentition on the inner margin of the falciger blades. The longest tentacular cirrus of $P$. singaporiensis reaches chaetiger 4 , while on $P$. rookeri sp. n. it reaches chaetiger 1 . The dorsal notopodial ligule on $P$. singaporiensis is conical anteriorly and triangular on median and posterior notopodia, $P$. rookeri sp. $n$. has subulate dorsal ligules on anterior notopodia and subtriangular on median and posterior notopodia. The falciger blades on $P$. singaporiensis are subtriangular and denticulate on $3 / 4$ of their length, whereas those of $P$. rookeri sp. $\mathrm{n}$. are subulate and denticulate for only $1 / 2$ of their length. The data listed here were taken based on Hutchings et al. (1991), who reviewed the holotype of $P$. singaporiensis. They note that this material is in very poor condition, however the pharyngeal arrangement, shape of the falcigers and number of chaetal lobes agree with their description. The original description from Grube (1878) differs from the Australian specimens in that the longest tentacular cirrus extends to segment 5 and in the pharyngeal arrangement: Area I= 2 cones in line; Area III $=23$ cones in transverse group with 2 cones on each side; Area $\mathrm{V}=1$ cone.

The range of Perinereis brevicirrata is the most geographically proximate to that of Perinereis rookeri sp. n., but the two can be readily distinguished morphologically. 


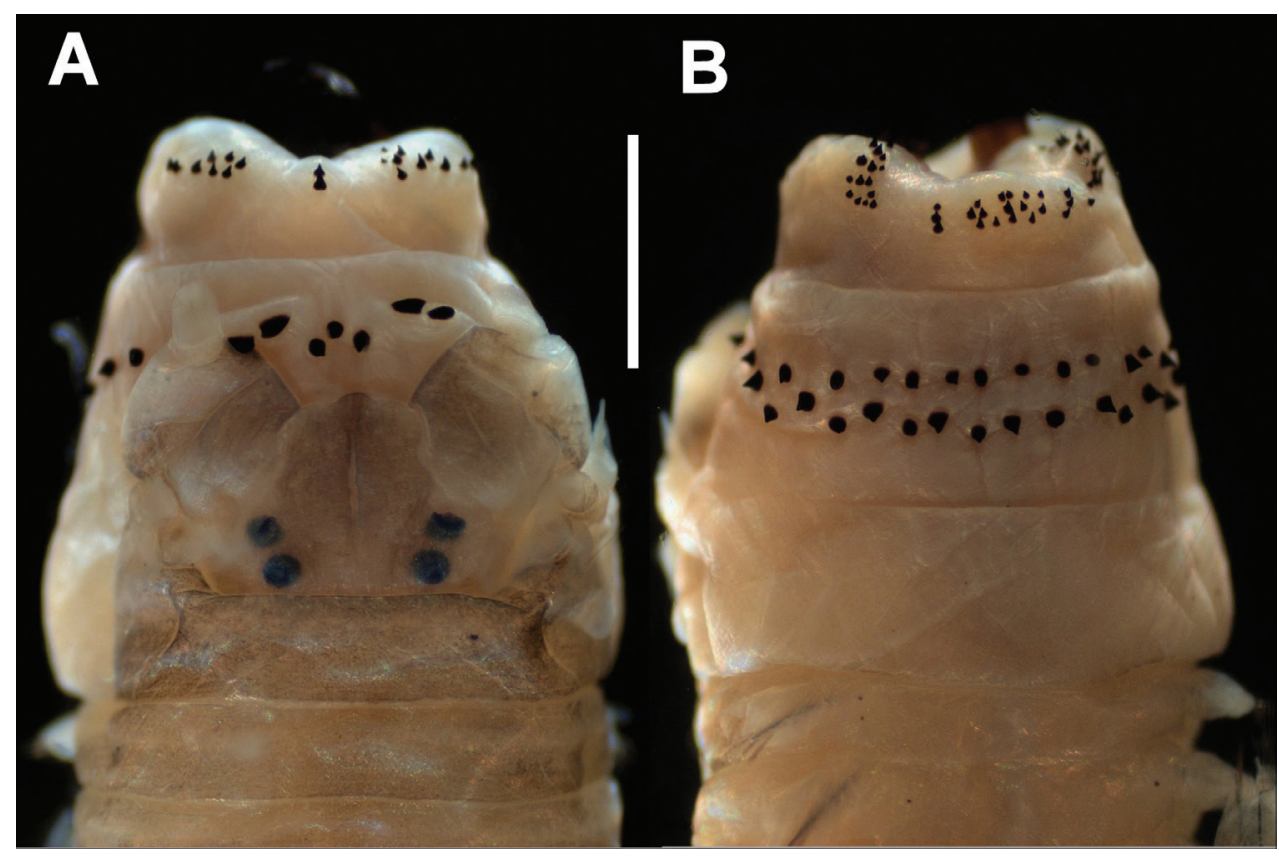

Figure 2. Perinereis rookeri sp. n. A Anterior end, dorsal view B Anterior end, ventral view. Measures: $\mathbf{A}-\mathbf{B}=1 \mathrm{~mm}$.

P. brevicirrata has notopodial prechaetal lobes, Area V has 2 large cones, and Area VII-VIII has 3 lines of paragnaths. In P. rookeri sp. n. notopodial prechaetal lobes are absent, Area V has 3 cones in a triangle, and Area VII-VIII has two well-defined lines of 33 paragnaths.

It is likely that Perinereis rookeri sp. n. specimens have been previously misidentified or grouped into a higher taxonomic group during previous benthic macroinvertebrate studies along the west coast of Florida.

Many studies throughout southwestern Florida collected only one species of Perinereis, P. floridana, including a 1932 survey conducted around the Dry Tortugas (Monro 1933) and a 1963 to 1969 Tampa Bay study, which included oyster reef sampling sites (Taylor 1971). Many subsequent studies from southwestern Florida showed an absence of Perinereis species completely, including a 1957-1960 estuarine ecology study in north Florida Bay (Tabb and Manning 1961). No Perinereis species were reported from within Rookery Bay during a 1984 to 1985 study; however, specimens labeled as Nereis or Neanthes sp. A were documented. The research also noted a lack of previous benthic macroinvertebrate research conducted specifically within Rookery Bay (Thoemke and Gyorkos 1988). A 2006 study focused on epifaunal community development associated with artificial oyster reefs created near St. Petersburg also found no Perinereis specimens, although four unidentified Annelida species were reported (Dow 2008). In northwestern Florida, during a systematic faunal inventory within Pensacola Bay from 1961-1963, three species of Perinereis were recorded, 
including $P$. andersonni, $P$. floridana, and an unidentified Perinereis species. All three species were considered rare, found only during the winter of 1962-1963 in areas with salinity at $20 \mathrm{ppt}$ or greater and within a sandy-mud benthic habitat (Cooley 1978). Taxonomic checklists for Florida list $P$. andersonni and $P$. floridana as the only two species of Perinereis found within Florida waters (Perkins and Savage 1975, Camp et al. 1998, Fauchald et al. 2009).

Due to the probable association Perinereis rookeri sp. n. has with oyster reefs, it is likely that any occurrence in previous studies would have been rare. Perinereis rookeri sp. n. specimens, if previously collected, have presumably been misidentified or left at a higher taxonomic level in earlier research from Florida's west coast.

Etymology. This specific name is derived from Rookery Bay National Estuarine Research Reserve on the west coast of Florida where the species was first discovered.

Distribution. This species is known from the Gulf of Mexico on the west coast of Florida, within Rookery Bay National Estuarine Research Reserve near Naples, where it was collected in association with oyster reefs in estuarine environments.

Ecological comments. Perinereis rookeri sp. n. was collected solely from oyster reefs within Rookery Bay National Estuarine Research Reserve. The oyster reefs located in Rookery Bay are shallow, intertidal reefs located in water depths of 1.2-1.5 m at high tide, with approximately $80 \%$ of the reefs exposed during low tide. Salinity at the sites where this species was found ranged from 35 to $37 \mathrm{ppt}$.

\section{Key to American species of Perinereis}

1 Area VI with more than 2 bars 2 Area VI with no more than 2 bars........................................................... 4 Posterior parapodia with dorsal ligule expanded; maxillary ring with few paragnaths (Area I and III without paragnaths); Area V with 1 paragnath; Area VI with 16 small paragnaths in a line.........P. seridentata (Hartmann-Schröder, 1959) Posterior parapodia without dorsal ligule expanded; numerous paragnaths in the maxillary ring. Area IV with bars; Area V with 1-2 paragnaths; Area VI with 12 to 16 small bars in a transverse line P. vallata (Grube, 1857) Area IV without bars; Area V with 3 paragnaths; Area VI with 5 to 10 small cones in a transverse line $P$. gualpensis Jeldes, 1961 Posterior parapodia with dorsal ligule not expanded .5 Posterior parapodia with dorsal ligule expanded. Notopodial prechaetal lobe present on anterior and median notopodia ......7 Notopodial prechaetal lobe absent ..........................................................6 Area VI with 1 transverse bar; Area V with 1-2 paragnaths in line; longest tentacular cirri reaching up to chaetiger 11 .... P. floridana Ehlers, 1868 Area VI with 2 bars; Area $V$ with 3 paragnaths in triangle; longest tentacular cirri reaching chaetiger 1 
Neuropodial heterogomph falcigers with short blades, with teeth on 3/4 of the inner edge. Longest tentacular cirri reaching chaetiger 3 to 5; Area I with 1 paragnath; Area $V$ with 3 paragnaths...P. camiguinoides (Augener, 1922) Neuropodial heterogomph falcigers with long blades, with teeth on $1 / 2$ of the inner edge; longest tentacular cirri not exceed the length of the prostomium; Areas I and $V$ with 2 paragnaths in a line ...P. brevicirrata (Treadwell, 1920) Area VI with 2 transverse bars.

Area VI with 1 transverse bar or a big conical paragnath Area VII-VIII with 8 paragnaths in a line; Area I with 4 paragnaths in a diamond; Area $V$ with 1 paragnath

P. osoriotafalli de León-González \& Solís-Weiss, 1998 Area I with 2 paragnaths in a line; Area III with 7 paragnaths in an oval group; Area V bare; neuropodial heterogomph falcigers with short blades ....

P. cariboea de León-González \& Solís-Weiss, 1998

11 Area VI with a short transverse bar or a big paragnath .............................12

Area I with 11 paragnaths in a group; Area III with 17 paragnaths in an oval group; Area $V$ with 2 paragnaths; neuropodial heterogomph falcigers with long blades......................................... mochimaensis Liñero-Arana, $1983^{1}$

Area VI with a long transverse bar .........................................................16

12 Area VI with a big cone shaped paragnath ...........................................13

Area VI with a short transverse bar ........................................................14

13 Anterior notopodia with notopodial prechaetal lobe; Area I with 1 paragnath; Area IV with 2 bars P. monterea (Chamberlin, 1918)

Notopodia without notopodial prechaetal lobe; Area I with 2 paragnaths in line and numerous small paragnaths on each side; Area IV without bars

P. falklandica (Ramsay, 1914)

14 Area IV usually with bars; notopodial prechaetal lobe absent; Area V with 3 paragnaths in triangle; Area VI with a short, straight bar

.P. pseudocamiguina (Augener, 1922)

Area IV without bars, only paragnaths; notopodial prechaetal lobe may be present

Notopodial prechaetal lobe evident on posterior notopodia; tentacular cirri long, reaching chaetiger 6-7; Area I and V with 1 paragnath

P. villalobosi Rioja, 1947

- $\quad$ Notopodial prechaetal lobe absent; tentacular cirri short, reaching chaetiger 1; Area I with 4 paragnaths in a diamond; Area $\mathrm{V}$ with 3 paragnaths in a triangle.

16 Area I with 2-3 paragnaths in line; Area $\mathrm{V}$ with 3 paragnaths in a triangle.... 17 Area I with a large group of paragnaths; Area $\mathrm{V}$ with 1 paragnath.

17 Tentacular cirri short, reaching chaetiger 2; neuropodial heterogomph falcigers with short blades P. longidonta Rozbaczylo \& Castilla, 1973 
- $\quad$ Tentacular cirri long, reaching chaetiger 7 to 9; neuropodial heterogomph falcigers with long blades ....................................P. helleri (Grube, 1878) ${ }^{2}$

18 Area VII-VIII with 7 small paragnaths in one line; Area I with a group of 7 paragnaths ...... P. bajacalifornica de León-González \& Solís-Weiss, 1998

- $\quad$ Area VII-VIII with paragnaths in two lines ............................................... 19

19 Area I with an oval group of 11 paragnaths; dorsal cirri inserted medially on posterior parapodia; falcigers with a distal tooth directed down

P. elenacosoae Rioja, 1947

- $\quad$ Area I with a triangular group of 8 paragnaths; dorsal cirri inserted subdistally on posterior parapodia; falcigers distally pointed ...P. ponteni Kinberg, $1865^{3}$

\section{Notes}

$1 \quad$ P. mochimaensis Liñero-Arana, 1983 and P. cariacoensis Liñero-Arana, 1983 differ in that $P$. mochimaensis has 5 transverse paragnaths in areas V and VI and posterior notopodial superior lobe larger. However, only one specimen of each was examined, one of them incomplete, and these are the only differences indicated. Therefore, until a revision is carried out we consider that $P$. cariacoensis could be a junior synonym of $P$. mochimaensis, which is why it was not included in the key.

$2 \quad P$. helleri was described by Grube (1878) from the Philippines and was reported from Pascua Island, Chile by Rozbaczylo and Castilla (1973). The characters described for the Chilean specimens, such as pharyngeal arrangement, are similar to those from the Philippines and Australia, however, the descriptions of Pascua Island's specimens were incomplete and were not accompanied by any illustration. Consequently, the presence of $P$. helleri in the Americas remains doubtful.

3 Perinereis ponteni Kinberg, 1865, was described from Rio de Janeiro, Brazil, the description was brief and very general. Hartman (1948) proposes a doubtful synonymy with $P$. anderssoni, however, both species can be easily distinguished by the presence of a long, ribbon shaped bar on the Area VI of $P$. ponteni, and a short bar on the same area in $P$. anderssoni. After the revision of one of the two existent syntypes, we consider that $P$. ponteni is valid.

\section{Additional notes}

Perinereis obfuscata was described from the Philippines by Grube (1878). Its occurrence has been documented from many coasts throughout the world, with great variability of morphological characters. The record of Rioja (1941) for western Mexico does not belong to this species; rather this record as well as that of Berkeley and Berkeley (1960) both from Guerrero, Mexico belong to Perinereis elenacasoae Rioja, 1947 (de León-González and Solís-Weiss 1998). For that reason P. obfuscata was not included in the key. 
Perinereis vancaurica was originally described from the Nicobar Islands, Andaman Sea. The records for America are limited to the Atlantic (Fauvel 1919, WesenbergLund 1958, Lana 1984, Santos and Lana 2000); however, the descriptions and illustrations provided in those works are insufficient to verify its presence in American waters. Lana (1984) provides a description and a figure of a median parapodium, but with only this information it is impossible to verify whether Lana's specimens belongs to the Andaman Sea species; furthermore, in the discussion section Lana mentioned that Perinereis brevicirrata could be similar to Perinereis vancaurica, but both species can be distinguished clearly by the presence of notopodial prechaetal lobe in P. brevicirrata and the absence of the same lobe in $P$. vancaurica. For that reason $P$. vancaurica was not included in the key.

\section{Acknowledgements}

We appreciate the efforts of the collection team, led by Dr Donna Devlin, included Dr Holly Nance, Dr Loren Coen, Pedro Lara, and Dana Smith. We would like to thank Elin Sigvaldadottir, who took some pictures for us of the anterior and posterior end of one of the two syntypes of Perinereis ponteni to revise the pharyngeal arrangement and parapodial structures. We are grateful to Chris Glasby, Robin Wilson, and an anonymous reviewer for providing valuable comments on the manuscript.

\section{References}

Bakken T, Wilson RS (2005) Phylogeny of nereidids (Polychaeta, Nereididae) with paragnaths. Zoologica Scripta, 34(5): 507-547. doi: 10.1111/j.1463-6409.2005.00200.x

Berkeley E, Berkeley C (1960) Notes on some Polychaeta from the west coast of Mexico, Panama, and California. Canadian Journal of Zoology 38: 357-362. doi: 10.1139/z60-040

Camp DK, Lyons WG, Perkins TH (1998) Checklists of selected shallow-water marine invertebrates of Florida. Florida Marine Research Institute Technical Reports TR-3: 1-238.

Cooley NR (1978) An inventory of the estuarine fauna in the vicinity of Pensacola, Florida. Florida Marine Research Publications 31: 1-119.

de León-González JA, Solís-Weiss V (1998) The genus Perinereis (Polychaeta: Nereididae) from Mexican littorals with the redescription of $P$. anderssoni and $P$. elenacasoae. Proceedings of the Biological Society of Washington 111(3): 674-693.

Dow IM (2008) Epifaunal assemblage of a newly established oyster reef with two substrates. Master's thesis, St. Petersburg, University of South Florida, Florida.

Fauchald KA, Granados-Barba A, Solís-Weiss V (2009) Polychaeta (Annelida) of the Gulf of Mexico. In: Felder DL, Camp DK (Eds) Gulf of Mexico-Origins, Waters, and Biota. Biodiversity. Texas A\&M Press, College Station, Texas, 751-788.

Fauvel P (1919) Annélides Polychètes de la Guyann francaise. Bulletin du Museum d'Histoire Naturelle 25(6): 472-479. 
Grube AE (1878) Annulata Semperiana. Beiträge zur kenntniss der anneliden fauna der Philippinen nach den von Herrn Prof. Semper mitgebrachten sammlungen. Memoires l' Académie Imperiale des Sciences de St. Pétersbourg, série 7, 25(8): 1-300, 15 pls.

Hartman O (1948) The Marine Annelids erected by Kinberg. With notes on some others types in the Swedish State Museum. Arkives för Zoologi 42A(1): 1-137.

Hutchings PA, Reid A, Wilson RS (1991) Perinereis (Polychaeta, Nereididae) from Australia, with redescriptions of six additional species. Records of the Australian Museum 43(3): 241-274. doi: 10.3853/j.0067-1975.43.1991.47

Kinberg JGH (1865) Annulata nova. Öfversigt af Förhandlingar Konglia Vetenskaps-Akadamiens 22: 167-179, 239-258.

Lana PC (1984) Anelideos poliquetas errantes do litoral do Estado do Paraná. PhD thesis, Instituto Oceanográfico, Universidade de San Paulo.

Monro CCA (1933) On a collection of Polychaeta from Dry Tortugas, Florida. Annals and Magazine of Natural History, 10,12(69): 244-269. doi: 10.1080/00222933308655413

Perkins TH, Savage T (1975) A bibliography and checklist of polychaetous annelids of Florida, the Gulf of Mexico, and the Caribbean Region. Florida Marine Research Publications 14: 1-62.

Read G, Fauchald K (2012) Nereididae. In: Read G, Fauchald, K. (2012). World Polychaeta database. Accessed through: World Register of Marine Species at http://www.marinespecies.org/aphia.php?p=taxdetails\&id=22496 (2013-03-13)

Rioja E (1941) Estudios Anelidológicos III. Datos para el conocimiento de la fauna de poliquetos de las costas del Pacífico de México. Anales del Instituto de Biología 12(2): 669-746.

Rozbaczylo N, Castilla JC (1973) El género Perinereis (Annelida, Polychaeta, Nereidae) en Chile. Studies on the Neotropical Fauna 8: 215-232. doi: 10.1080/01650527309360463

Santos CSG, Lana PC (2000) Nereididae (Annelida, Polychaeta) da costa nordeste do Brasil. I. Padróes regionais e zoogeográficos de distribuicao. Iheringia, Ser. Zool. 88: 181-188.

Tabb DC, Manning RB (1961) A checklist of the flora and fauna of northern Florida Bay and adjacent brackish waters of the Florida mainland collected during the period July, 1957 through September, 1960. Bulletin of Marine Science of the Gulf and Caribbean 11 (4): 552-649.

Taylor JL (1971) Polychaetous annelids and benthic environment in Tampa Bay, Florida. $\mathrm{PhD}$ thesis, Gainesville, University of Florida, Florida.

Thoemke KW, Gyorkos KP (1988) Distribution and abundance of benthic invertebrates in Rookery Bay National Estuarine Research Reserve: Final Report, Revised. Rookery Bay National Estuarine Research Reserve, 1-59.

Wesenberg-Lund E (1958) Lesser Antillean polychaetes chiefly from brackish waters with a survey and a bibliography of fresh and brackish-water polychaetes. Studies on the Fauna of Curacao and other Caribbean Islands 8: 1-41. 